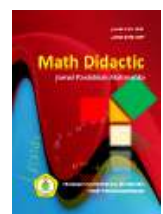

MATH DIDACTIC: JURNAL PENDIDIKAN MATEMATIKA

Volume 4 Nomor 3, September - Desember 2018, halaman 190 - 201

Tersedia Daring pada http://jurnal.stkipbjm.ac.id/index.php/math

\title{
PROSES PEMECAHAN MASALAH OPERASI ALJABAR OLEH SISWA SMP BERDASARKAN TAHAPAN IDEAL DITINJAU DARI KEMAMPUAN MATEMATIKA
}

\section{THE PROBLEM SOLVING PROCESS OF ALGEBRAIC OPERATIONS BY JUNIOR HIGH SCHOOL STUDENTS BASED ON IDEAL STAGES IN TERMS OF MATHEMATICAL ABILITIES}

Ardiani Rahma Putri, Danang Setyadi, Helti Lygia Mampouw

Program Studi Pendidikan Matematika FKIP Universitas Kristen Satya Wacana 202015071@student.uksw.edu, danang.setyadi@staff.uksw.edu, helti.mampouw@staff.uksw.edu

\begin{abstract}
Abstrak: Penelitian ini bertujuan untuk mendeskripsikan proses pemecahan masalah operasi aljabar oleh siswa SMP berdasarkan tahapan IDEAL ditinjau dari kemampuan matematika. Jenis penelitian ini adalah deskriptif kualitatif. Instrumen utama dalam penelitian ini adalah peneliti sendiri, dibantu dengan lembar tes pemecahan masalah dan pedoman wawancara. Metode penelitian data pada penelitian ini adalah tes, wawancara, dan dokumentasi. Penelitian ini menggunakan teknik reduksi data, penyajian data dan penarikan kesimpulan dalam analisis data. Data yang dianalisis adalah proses pemecahan masalah berdasarkan kelima tahapan IDEAL yaitu mengidentifikasi masalah, mendefinisikan masalah, mengeksplorasi strategi, melaksanakan rencana, dan mengkaji kembali. Subjek terpilih adalah tiga siswa kelas VIII SMP Negeri 1 Salatiga. Hasil penelitian menunjukkan bahwa pada subjek dengan kemampuan matematika tinggi mampu melaksanakan kelima tahapan tersebut, subjek dengan kemampuan matematika sedang hanya mampu melaksanakan kelima tahapan pada soal terbuka tipe 1 dan tidak melaksanakan tahap mengkaji kembali pada soal terbuka tipe 2 dan soal tertutup. Pada subjek dengan kemampuan matematika rendah hanya melaksanakan keempat tahapan pada soal terbuka tipe 1 dan soal tertutup, serta tiga tahapan pada soal terbuka tipe 2.
\end{abstract}

Kata Kunci: Pemecahan Masalah, IDEAL, Aljabar

Abstract: This research aims to describe the problem solving process of algebraic operations by junior high school students is based on IDEAL stages in terms of mathematical abilities. The type of this research is descriptive qualitative. The main instrument in this study is the researchers themselves, assisted problem solving test and interview guides. Data research methods in this study are tests, interviews, and documentation. This study use data reduction techniques, data presentation, dan conclusion drawing in data analysis. Data analyzed is problem solving procces based on the five IDEAL stages, namely identify problem, define the problem, explore alternative approaches, acting on a plan, and looking the effects. The selected subject is three students in grade VIII in SMP N 1 Salatiga. The result showed that in subjects with high mathematical abilities capable to finish these five stages, subjects with moderate mathematical abilities are only able to finish the five stages in open questions type 1 and can not finish the stages of reviewing open questions type 2 and closed questions. In subjects with low mathematical abilities only finish the four stages in open questions type 1 and closed questions, and three stages in open questions 2 .

Keywords: Problem Solving, IDEAL, ALgebraic

Cara Sitasi: Putri, A.R., Setyadi, D., \& Mampouw, H.L. (2018). Proses pemecahan masalah operasi aljabar oleh siswa SMP berdasarkan tahapan IDEAL ditinjau dari kemampuan matematika. Math Didactic: Jurnal Pendidikan Matematika, 4(3), 190-201. 
Kemampuan pemecahan masalah merupakan suatu hal yang penting dalam pembelajaran matematika. Pentingnya kemampuan pemecahan masalah diungkapkan oleh Schoenfeld (Munalikatasari, 2016, hal. 113) yang mengemukakan bahwa "there is a general acceptance of the idea that primary goal of mathematics instruction should be to have students become competent problem solver". Pernyataan tersebut bermakna bahwa pemecahan masalah harus menjadi fokus dari matematika sekolah dan tujuan utama dari pembelajaran matematika adalah menjadikan siswa memiliki kompetensi dalam memecahkan masalah. Anggo (2011, hal. 38) menjelaskan bahwa melalui pemecahan masalah matematika, siswa diarahkan untuk mengembangkan kemampuannya antara lain membangun pengetahuan matematika yang baru, memecahkan masalah dalam berbagai konteks yang berkaitan dengan matematika, menerapkan berbagai strategi yang diperlukan, dan merefleksikan proses pemecahan masalah matematika

Pemecahan masalah adalah suatu cara berpikir secara ilmiah untuk mencari jawaban atau penyelesaian dari suatu masalah (Djamarah, 2002, hal. 12). Dalam menyelesaikan masalah matematika, dibutuhkan langkah pemecahan yang tepat guna menyelesaikan masalah tersebut. Salah satu langkah pemecahan yang dapat digunakan adalah langkah pemecahan model Bransford and Stein. Pemecahan masalah menurut model Bransford and Stein adalah IDEAL problem solving yaitu model penyelesaian masalah yang mampu meningkatkan kemampuan berpikir dan meningkatkan keterampilan dalam proses penyelesaian masalah (J \& Stein, 1993, hal. 9).
Dalam penyelesaian masalah juga dibutuhkan pemahaman siswa terhadap masalah. Pemahaman siswa dapat dipengaruhi oleh kemampuan matematika yang dimilikinya. Hal tersebut sesuai dengan hasil penelitian yang dilakukan oleh Siswono (2008, hal. 40) bahwa kemampuan siswa terhadap konsep matematika yang berbeda tingkatnya menimbulkan perbedaan pada kemampuan siswa dalam menyelesaikan soal matematika. Menurut Hammadah (2017, hal. 43) profil kemampuan matematika dalam memecahkan soal open-ended untuk siswa yang berkemampuan tinggi sudah baik, sedangkan untuk siswa yang berkemampuan sedang dan rendah perlu ada peningkatan. Dengan demikian, proses pemecahan masalah siswa dalam menyelesaikan masalah matematika juga berbeda-beda bergantung pada tingkat kemampuan matematika yang mereka miliki.

Hasil observasi yang sudah dilakukan di Sekolah Menengah Pertama pada bulan November 2017 menunjukkan bahwa siswa cenderung mengalami kesulitan dalam memecahkan masalah matematika selama pembelajaran ketika dihadapkan dengan soal tentang operasi hitung aljabar. Amir (2016, hal. 9) menyatakan bahwa kemampuan pemecahan masalah siswa SMP belum optimal, rata rata kelas sudah mencapai KKM, namun belum tuntas secara klasikal pada materi aljabar. Hal ini diperkuat oleh Laporan Hasil Ujian Nasional SMP/MTs Tahun 2016/2017 dan tahun 2015/2016, bahwa daya serap matematika pada materi Aljabar mengalami penurunan dari tahun $2015 \mathrm{ke}$ tahun 2016 yaitu dari $52,97 \%$ ke $48,60 \%$ selanjutnya pada tahun 2016 materi aljabar daya serapnya menduduki posisi terendah kedua dibandingkan dengan materi lain. Hasil tersebut dapat dilihat dalam tabel 1.1 berikut. 
Tabel 1.1

Hasil Ujian Nasional

\begin{tabular}{llllll}
\hline & $\begin{array}{c}\text { Kemam } \\
\text { puan }\end{array}$ & \multicolumn{2}{c}{ Provinsi } & \multicolumn{2}{c}{ Nasional } \\
No & $\begin{array}{l}\text { Yang } \\
\text { Diuji }\end{array}$ & $\mathbf{2 0 1 5 /}$ & $\mathbf{2 0 1 6 /}$ & $\mathbf{2 0 1 5} /$ & $\mathbf{2 0 1 6}$ \\
& & $\mathbf{2 0 1 7}$ & $\mathbf{2 0 1 6}$ & $\mathbf{2 0 1 7}$ \\
\hline 1 & Bilangan & 47.73 & 50.85 & 52.74 & 51.05 \\
2 & Aljabar & 45.33 & 44.95 & 52.97 & 48.60 \\
3 & $\begin{array}{l}\text { Geometri } \\
\text { dan }\end{array}$ & & & & \\
& $\begin{array}{l}\text { Pengukur } \\
\text { an }\end{array}$ & 40.26 & 45.78 & 47.19 & 48.57 \\
4 & $\begin{array}{l}\text { Statistika } \\
\text { dan }\end{array}$ & 40.82 & 58.69 & 46.73 & 56.40 \\
& Peluang & & & & \\
\hline
\end{tabular}

Rendahnya daya serap siswa pada materi Aljabar dalam Ujian Nasional mengindikasikan bahwa siswa masih mengalami kesulitan dalam mempelajari materi aljabar. Dengan demikian, secara tidak langsung juga mengindikasikan bahwa siswa mengalami kesulitan dalam memecahkan masalah operasi hitung aljabar. Oleh karena itu, guru perlu mengetahui bagaimana pemahaman siswa pada materi tersebut. Karena dengan mengetahui pemahaman tersebut, guru dapat membantu siswa untuk meningkatkan pemahamannya.'

Berdasarkan uraian diatas, peneliti melakukan penelitian pada siswa SMP dengan judul "proses pemecahan masalah operasi aljabar oleh siswa smp berdasarkan tahapan IDEAL ditinjau dari kemampuan matematika". Penelitian ini bertujuan untuk mendeskripsikan proses pemecahan masalah operasi aljabar oleh siswa SMP berdasarkan tahapan IDEAL ditinjau dari kemampuan matematika.

\section{Metode Penelitian}

Metode yang digunakan dalam penelitian ini adalah kualitatif dengan jenis penelitian ini yaitu penelitian deskriptif. Penelitian ini mendeskripsikan proses pemecahan masalah dalam mengerjakan soal operasi aljabar pada siswa kelas VIII SMP Negeri 1 Salatiga berdasarkan tahapan pemecahan masalah IDEAL.

Subjek dalam penelitian ini adalah siswa kelas VIII SMP Negeri 1 Salatiga pada semester ganjil tahun pelajaran 2018/2019. Penelitian ini diawali dengan penentuan tingkat kemampuan matematika siswa berdasarkan hasil penilaian akhir semester genap tahun pelajaran 2017/2018. Siswa dikategorikan ke dalam tiga tingkatan kemampuan matematika yaitu tinggi, sedang, dan rendah. Dari masing-masing kategori tersebut dipilih satu siswa sebagai subjek penelitian. Kemampuan subjek dalam mengemukakan pendapat atau proses berpikirnya secara lisan maupun tulisan juga menjadi pertimbangan dalam menentukan subjek penelitian, hal ini ditujukan agar subjek dalam penelitian dapat mendukung keterlaksanaan penelitian.

Instrumen utama penelitian ini adalah peneliti sendiri yang dibantu dengan instrumen bantu berupa soal tes pemecahan masalah dan pedoman wawancara. Soal tes yang diberikan berupa soal operasi aljabar sebanyak 3 soal. Oleh karena itu, sumber data utama dalam penelitian adalah lembar pekerjaan siswa dan kata-kata yang menunjukkan proses pemecahan masalah oleh siswa dalam menyelesaikan soal operasi aljabar. Data yang didapatkan meliputi lembar hasil pekerjaan siswa dan rekaman wawancara siswa yang telah ditulis dalam sebuah transkrip. 


\section{Hasil Penelitian dan Pembahasan}

\section{Hasil}

Hasil penelitian berupa deskripsi proses pemecahan masalah operasi aljabar oleh siswa berdasarkan tahapan IDEAL ditinjau dari kemampuan matematika. Berdasarkan hasil pekerjaan dari 3 siswa kelas VIII SMP, peneliti mendeskripsikan proses pemecahan masalah oleh masing-masing subjek pada setiap soal yang diberikan.

\section{Deskripsi Proses Pemecahan Masalah Subjek Pada Soal Nomor 1 (Soal \\ Terbuka Tipe 1)}

Hasil penelitian menunjukkan bahwa subjek dengan kemampuan matematika tinggi mengalami kelima tahapan IDEAL. Pada tahap meingidentifikasi masalah, subjek berkemampuan tinggi yaitu LR, menuliskan apa yang diketahui dalam soal yaitu $(a+4)+$ $(b-3)=13$ dan $(a-1)-(b+4)=1$, kemudian pada tahap mendefinisikan masalah LR menuliskan apa yang ditanyakan yaitu menuliskan hasil bagi dan hasil kali $a$ dan $b$. Pada tahap mengeksplorasi strategi LR memikirkan rencana yang akan digunakan untuk memecahkan masalah pada soal 1, yaitu LR akan menjabarkan persamaan, kemudian LR akan mencari nilai $b$ dengan cara eliminasi, setelah nilai $b$ diketahui, LR mencari nilai $a$ dengan cara substitusi nilai $b$ yang sudah diketahui ke persamaan $(a+b=12)$, selanjutnya LR mencari hasil bagi dan hasil kali dari dua nilai tersebut. Berikut adalah cuplikan wawancara yang menunjukkan hal tersebut.

R104 : Aku menulis dulu yang diketahui dari soal sama yang ditanyakan. Terus habis itu menjabarkan persamaan, kemudian mencari nilai b dengan cara eliminasi, setelah itu mencari nilai a dengan cara substitusi nilai b yang sudah diketahui ke persamaan ini (sambil menunjuk jawabannya). Kemudian jika sudah ketemu nilai keduanya, mencari hasil bagi dan hasil kali dari dua nilai tersebut.

Pada tahap melaksanakan rencana, LR menerapkan rencana yang sudah dibuat pada tahap sebelumnya. Pertama-tama LR menjabarkan persamaan dan mencari nilai $b$ dengan cara eliminasi seperti yang terlihat pada Gambar 1.

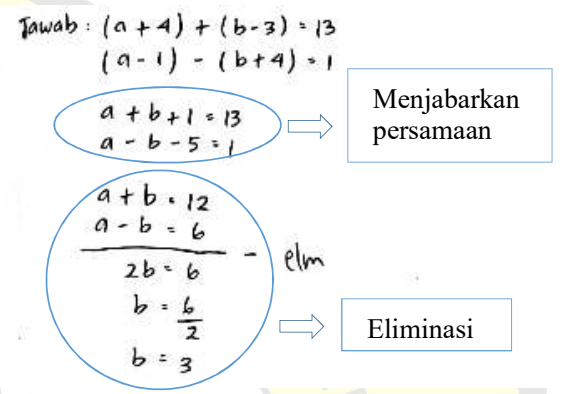

Gambar 1. Hasil Pekerjaan LR pada Soal 1

LR menggunakan metode substitusi untuk mencari nilai $a$, kemudian mencari hasil bagi dan hasil kali dari $a$ dan $b$ yang sudah diketahui seperti yang terlihat pada Gambar 2.

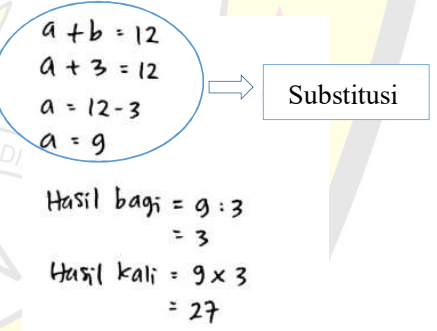

Gambar 2. Hasil Pekerjaan LR pada soal 1

Pada tahap yang terakhir yaitu tahap mengkaji kembali dan mengevaluasi pengaruh, setelah LR memperoleh hasil $a=9$ dan $b=3$, langkah yang dilakukannya adalah mensubstitusikan nilai $a$ dan nilai $b$ pada salah satu persamaan diawal untuk memastikan hasil yang sudah diperolehnya, ditampilkan pada Gambar 3.

$$
\begin{aligned}
& a-b=6 \\
& 9-3=6
\end{aligned}
$$

Gambar 3. Hasil Pekerjaan LR pada soal 1 
Subjek dengan kemampuan matematika sedang yaitu NA, mengalami kelima tahapan pemecahan IDEAL pada soal 1. Pada tahap meingidentifikasi masalah, NA menuliskan apa yang diketahui dalam soal yaitu $a+4$ dan $b+3=13$ serta $a-$ 1 dan $b+4=1$. Pada tahap mendefinisikan masalah, NA menuliskan apa yang ditanyakan yaitu menuliskan hasil bagi dan hasil kali kedua bilangan, selanjutnya pada tahap mengeksplorasi strategi yang mungkin, NA memikirkan rencana yang akan digunakan untuk memecahkan masalah tersebut. NA akan menjabarkan persamaan, kemudian NA akan mencari nilai $a$ dengan cara eliminasi, setelah nilai $a$ diketahui, NA mencari nilai $b$ dengan cara eliminasi kembali. Selanjutnya NA mencari hasil bagi dan hasil kali dari dua nilai tersebut. Berikut adalah cuplikan wawancara yang menunjukkan hal tersebut.

A101 : Menjabarkan dari yang diketahui bu, lalu menggunakan cara eliminasi untuk mendapatkan nilai a dan b bu. Lalu memasukkan atau mengerjakan dalam soal yang dikali dan dibagi.

Pada tahap melaksanakan rencana, NA menerapkan rencana yang sudah dibuat pada tahap sebelumnya seperti terlihat pada Gambar 4. Pada tahap yang terakhir yaitu tahap mengkaji kembali dan mengevaluasi pengaruh, langkah yang dilakukan NA adalah mensubstitusikan nilai $a$ dan nilai $b$ pada persamaan diawal.

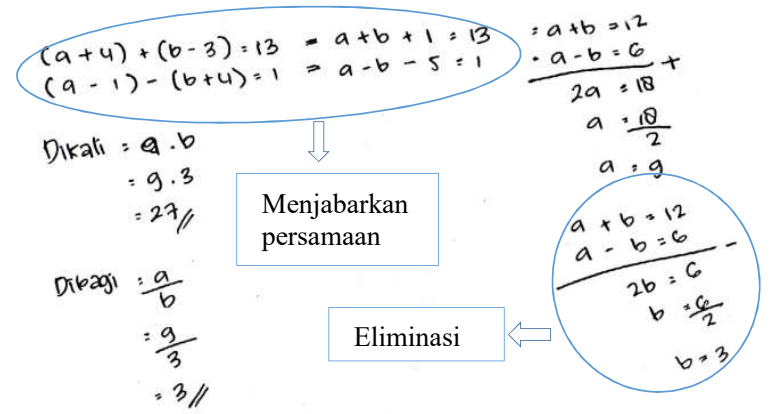

Gambar 4. Hasil pekerjaan NA pada soal 1
Pada subjek dengan kemampuan matematika rendah, yaitu AR. Berdasarkan hasil tes dan wawancara, AR tidak mengalami kelima tahapan IDEAL, subjek hanya mengalami keempat tahapan. Pada tahap meingidentifikasi masalah, AR menuliskan apa yang diketahui dalam soal, yaitu $(a+$ $4)+(b-3)=13$ dan $(a-1)-(b+4)=$ 1. Pada tahap mendefinisikan masalah, AR menuliskan apa yang ditanyakan yaitu menuliskan hasil bagi dan hasil kali $a$ dan $b$, selanjutnya pada tahap mengeksplorasi strategi yang mungkin, AR memikirkan rencana yang akan digunakan untuk memecahkan masalah tersebut. AR akan menjabarkan persamaan, kemudian AR akan mencari nilai a dengan cara eliminasi, setelah nilai $a$ diketahui, AR mencari nilai $b$ dengan cara substitusi nilai $a$ yang sudah diketahui ke persamaan $(a+b=$ 12). Selanjutnya AR mencari hasil bagi dan hasil kali dari dua nilai tersebut. Berikut adalah cuplikan wawancara yang menunjukkan hal tersebut.

R103 : Dijabarkan dulu persamaannya, terus pakai cara eliminasi untuk cari nilai a terus disubstitusi bu. Terus kalau sudah dicari hasil kali sama baginya.

Pada tahap melaksanakan rencana, AR melaksanakan rencana yang sudah dibuatnya sesuai dengan tahap sebelumnya. AR menjabarkan terlebih dahulu persamaanpersamaan yang diketahui, seperti yang terlihat dalam Gambar 4.

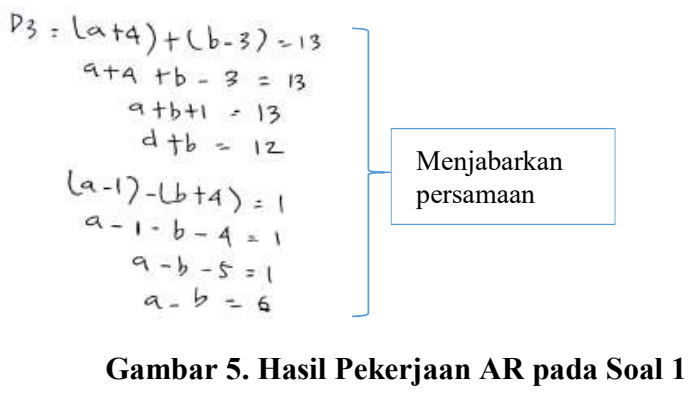

Gambar 5. Hasil Pekerjaan AR pada Soal 1 
AR menggunakan metode eliminasi dan substitusi untuk mencari nilai $a$ dan $b$, seperti yang terlihat pada Gambar 6. Pada tahap yang terakhir yaitu tahap mengkaji kembali dan mengevaluasi pengaruh, AR tidak memeriksa kembali hasil yang diperolehnya, namun AR yakin bahwa hasil pekerjaannya sudah benar.
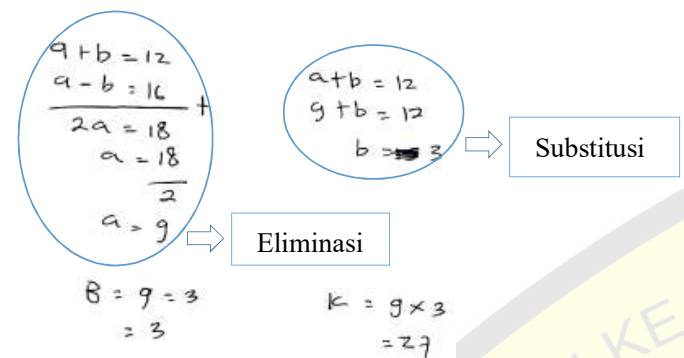

Gambar 6. Hasil Pekerjaan AR pada Soal 1

\section{Deskripsi Proses Pemecahan Masalah}

\section{Subjek Pada Soal Nomor 2 (Soal}

\section{Terbuka Tipe 2)}

Hasil penelitian menunjukkan bahwa subjek dengan kemampuan matematika tinggi mengalami kelima tahapan IDEAL. Pada tahap meingidentifikasi masalah, subjek berkemampuan tinggi, menuliskan apa yang diketahui dalam soal, yaitu $(4 x+2 y)(a x+$ by) $\left.=c x^{2}+16 x y+10 y^{2}\right)$. Pada tahap mendefinisikan masalah, LR menuliskan apa yang ditanyakan pada soal yaitu mencari nilai $a, b$, dan $c$ serta nilai $(a+b)^{2}+(a-c)^{2}$, selanjutnya pada tahap mengeksplorasi strategi yang mungkin, LR memikirkan rencana yang akan digunakan untuk memecahkan masalah tersebut, yaitu LR akan mengkali pelangi persamaan pada ruas kiri terlebih dahulu, lalu menjabarkan, kemudian menjadi persamaan polynomial. LR mendapatkan persamaanpersamaan baru dan juga mendapatkan nilai $b$, kemudian nilai tersebut disubstitusikan pada persamaan-persamaan yang baru untuk mendapatkan nilai $a$ dan $c$. Selanjutnya LR mencari nilai dari $(a+b)^{2}+(a-c)^{2}$.
Berikut adalah cuplikan wawancara yang menunjukkan hal tersebut.

R204 : Oh iya bu dikali pelangi dulu, dijabarin terus kalo udah kan jadi persamaan polinomial bu. Terus habis itu kalau udah ketemu sebelah kanan kan sama dengan sebelah kiri bu (sambil menunjukkan lembar jawabannya). Nanti jadi dapat persamaan baru lagi bu, terus di substitusi buat cari nilai a dan c nya bu. Terus habis itu kalau sudah ketemu nilai a, b, dan c nyari nilai $a+b$ blabla itu bu (sambil menunjukkan lembar jawabannya), ketemu deh bu.

Pada tahap melaksanakan rencana, LR menerapkan rencana yang telah dibuat pada tahap sebelumnya, seperti yang terlihat pada Gambar 7.

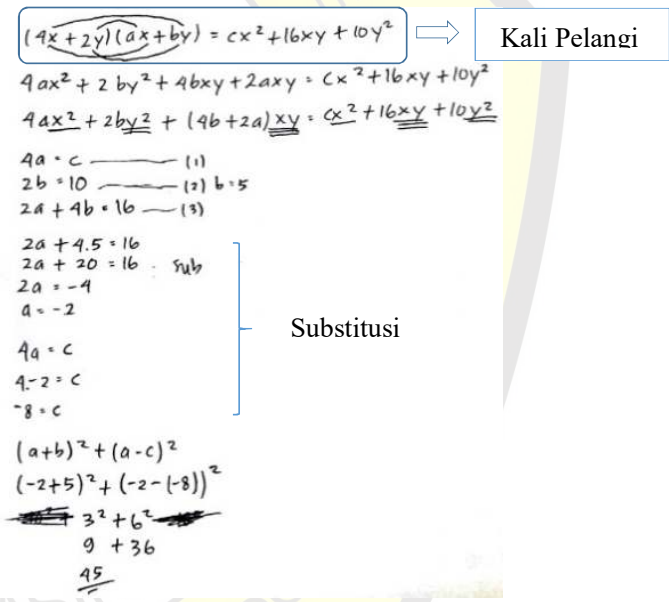

Gambar 7. Hasil pekerjaan LR pada soal 2

Pada tahap yang terakhir yaitu tahap mengkaji kembali dan mengevaluasi pengaruh, LR mensubstitusikan nilai $a, b$ dan nilai $c$ pada persamaan diawal untuk memastikan hasil yang telah diperolehnya.

Subjek dengan kemampuan matematika sedang, mengalami keempat tahapan pemecahan IDEAL pada soal 2. Pada tahap meingidentifikasi masalah, NA menuliskan apa yang diketahui dalam soal, yaitu $(4 x+2 y)(a x+b y)=c x^{2}+16 x y+$ $\left.10 y^{2}\right)$. Pada tahap mendefinisikan masalah, 
NA menuliskan apa yang ditanyakan yaitu mencari nilai $a, b$, dan $c$ serta nilai $(a+b)^{2}+$ $(a-c)^{2}$, selanjutnya pada tahap mengeksplorasi strategi yang mungkin, NA memikirkan rencana yang akan digunakan untuk memecahkan masalah tersebut yaitu NA akan mengali pelangi persamaan pada ruas kiri terlebih dahulu, lalu menjabarkan, kemudian menjadi persamaan polynomial. NA mendapatkan persamaan-persamaan baru dan juga mendapatkan nilai $b$, kemudian nilai tersebut disubstitusikan pada persamaanpersamaan yang baru untuk mendapatkan nilai $a$ dan $c$. Selanjutnya NA mencari nilai dari $(a+b)^{2}+(a-c)^{2}$. Berikut adalah cuplikan wawancara yang menunjukkan hal tersebut.

A201 : Menggunakan palang pelangi, terus dijabarkan dapat persamaan 1, 2, 3 . Lalu dimasuk masukkan yang sudah diketahui buat cari nilai $a, b, c$ nya.

Pada tahap melaksanakan rencana, NA menerapkan dan melaksanakan rencana sesuai dengan yang sudah dibuatnya pada tahap sebelumnya, seperti terlihat pada Gambar 8 .

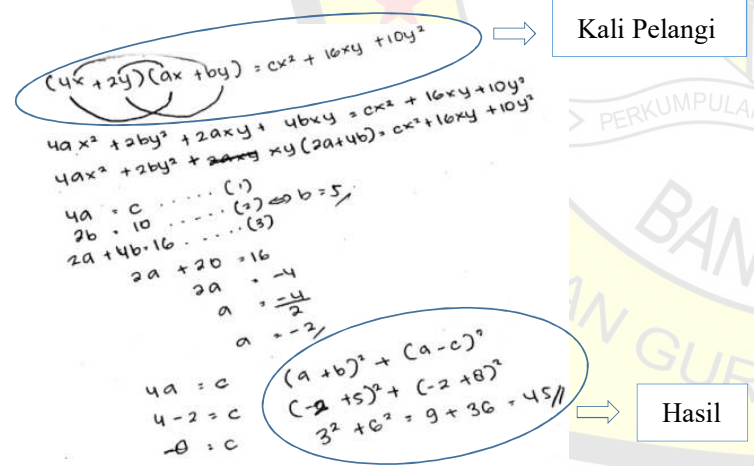

\section{Gambar 8. Hasil pekerjaan NA pada soal 2}

Pada tahap yang terakhir yaitu tahap mengkaji kembali dan mengevaluasi pengaruh, NA tidak memeriksa kembali hasil yang diperolehnya, hal ini terlihat saat wawancara. NA menyebutkan hal tersebut. Namun, NA yakin bahwa hasil pekerjaannya sudah benar.
Pada subjek dengan kemampuan matematika rendah, AR hanya mengalami keempat tahapan IDEAL. Pada tahap meingidentifikasi masalah, AR menuliskan apa yang diketahui dalam soal, yaitu $(4 x+$ $\left.2 y)(a x+b y)=c x^{2}+16 x y+10 y^{2}\right)$. Pada tahap mendefinisikan masalah, AR menuliskan apa yang ditanyakan yaitu mencari nilai $a, b$, dan $c$ serta nilai $(a+b)^{2}+$ $(a-c)^{2}$, selanjutnya pada tahap mengeksplorasi strategi yang mungkin, AR memikirkan rencana yang akan digunakan untuk memecahkan masalah tersebut. AR akan mengali pelangi persamaan pada ruas kiri terlebih dahulu, lalu menjabarkannya. Selanjutnya AR mencari nilai dari $(a+b)^{2}+$ $(a-c)^{2}$. Berikut cuplikan wawancara yang menunjukkan hal tersebut.

R203 : Mungkin dikali pelangi dulu bu terus dijabarin. Nanti ketemu nilainya bu.

Pada tahap melaksanakan rencana, AR menerapkan rencana yang sudah dibuatnya pada tahap sebelumnya, namun AR tidak menyelesaikannya, AR hanya sampai pada menjabarkannya dan AR sudah menyerah tidak melanjutkannya kembali, seperti terlihat pada Gambar 9. Hal tersebut juga ditunjukkan dengan cuplikan wawancara berikut ini.

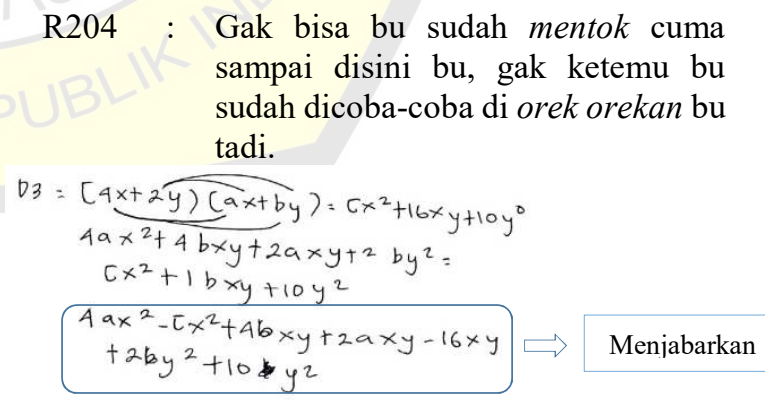

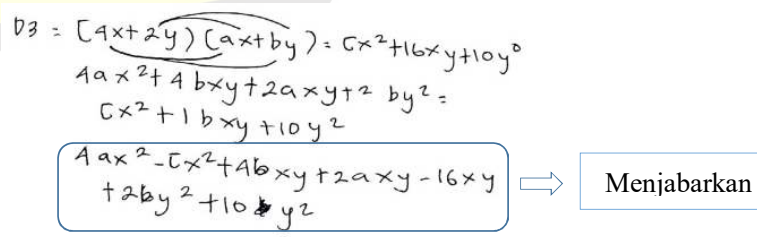

Gambar 9. Hasil pekerjaan AR pada soal 2

Pada tahap yang terakhir yaitu tahap mengkaji kembali dan mengevaluasi pengaruh, AR tidak melaksanakan tahapan ini. 


\section{Deskripsi Proses Pemecahan Masalah Subjek Pada Soal Nomor 3 (Soal Tertutup)}

Hasil penelitian menunjukkan bahwa subjek dengan kemampuan matematika tinggi mengalami kelima tahapan IDEAL. Pada tahap meingidentifikasi masalah, subjek berkemampuan tinggi, menuliskan apa yang diketahui dalam soal, yaitu $5+x+y=$ 55 dan $5=6 y$. Pada tahap mendefinisikan masalah, LR menuliskan apa yang ditanyakan yaitu umur ayah dan umur anaknya, selanjutnya pada tahap mengeksplorasi strategi yang mungkin, LR memikirkan rencana yang akan digunakan untuk memecahkan masalah tersebut. Pertama LR akan mengubah ke dalam bentuk kalimat matematika terlebih dahulu, kemudian LR menjabarkan persamaan tersebut, dan yang terakhir LR menggunakan metode substitusi untuk mencari nilai $x$ dan $y$. Berikut adalah cuplikan wawancara yang menunjukkan hal tersebut.

R304 : Pertama aku rubah dulu bu ke kalimat matematika terus habis itu aku jabarin bu persamaannya, terus aku subtitusi kesalah satu persamaan buat cari nilai $x$ nya ini bu (sambil menunjuk lembar jawabannya). Habis itu aku substitusiin lagi buat cari nilai $y$ nya bu. Terus ketemu bu umurnya.

LR juga menjelaskan dalam wawancara jika $x$ adalah umur ayah dan $y$ adalah umur anak.

R305: $\begin{aligned} & \text { Oh iya bu tadi belum aku tulis bu } \\ & \text { lupa, umur ayah itu yang } x \text { terus yang } \\ & y \text { itu umur anaknya bu. }\end{aligned}$

Pada tahap melaksanakan rencana, LR menerapkan rencana sesuai yang telah dibuat pada tahap sebelumnya, LR menggunakan metode substitusi untuk mendapatkan nilai $\mathrm{x}$, seperti terlihat pada Gambar 10.

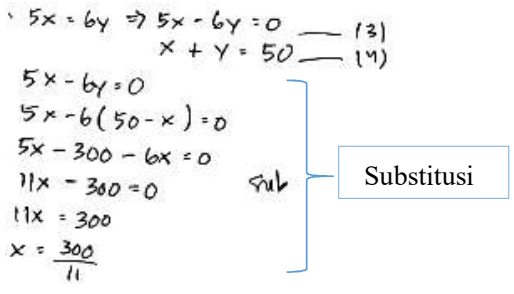

Gambar 10. Hasil pekerjaan LR pada soal 3

Kemudian untuk mendapatkan nilai y, LR juga menggunakan metode substitusi, seperti pada Gambar 11. Pada tahap yang terakhir yaitu tahap mengkaji kembali dan mengevaluasi pengaruh, LR melakukan pengecekan kembali. Meskipun LR melaksanakan kelima tahapan IDEAL, namun jawaban dari LR tetap belum benar.

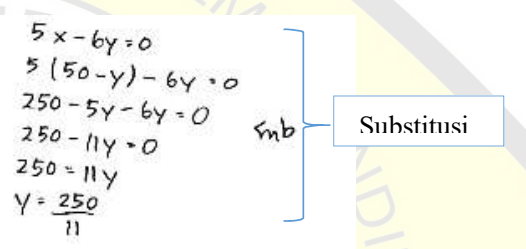

Gambar 11. Hasil pekerjaan LR pada soal 3 Subjek dengan kemampuan matematika sedang, mengalami keempat tahapan pemecahan IDEAL pada soal 3. Pada tahap meingidentifikasi masalah, NA menuliskan apa yang diketahui dalam soal, yaitu $5 x=6 y$ dan $5+x+y=55$ serta $x=$ ayah dan $y=$ anak. Pada tahap mendefinisikan masalah, NA menuliskan apa yang ditanyakan yaitu umur ayah dan umur anaknya, selanjutnya pada tahap mengeksplorasi strategi yang mungkin, NA memikirkan rencana yang akan digunakan untuk memecahkan masalah tersebut. Pertama NA akan mengubah dari soal cerita ke bentuk kalimat matematika terlebih dahulu, kemudian NA menjabarkan persamaan tersebut, dan yang terakhir NA menggunakan metode eliminasi untuk mencari nilai $x$ dan $y$. Berikut adalah cuplikan wawancara yang menunjukkan hal tersebut. 


\section{A301 : Mengubah soal cerita menjadi kalimat matematika, lalu menggunakan cara eliminasi buat cari umur ayah dan umur anaknya bu.}

Pada tahap melaksanakan rencana, NA melaksanakan rencana sesuai dengan yang sudah dibuatnya pada tahap sebelumnya, seperti terlihay pada Gambar 12. Pada tahap yang terakhir yaitu tahap mengkaji kembali dan mengevaluasi pengaruh, NA tidak melakukan pengecekan kembali. Jawaban NA tetaplah belum benar meskipun NA mengerjakan soal tersebut hingga akhir dan merasa sudah yakin dengan jawaban yang diperolehnya.

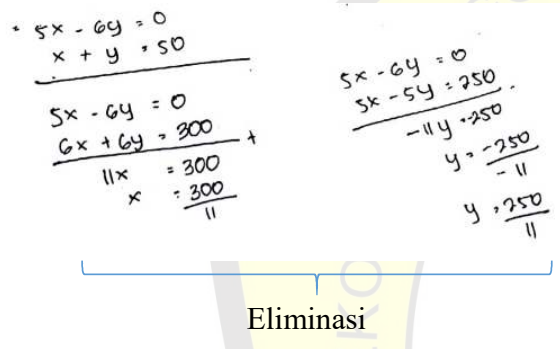

Gambar 12. Hasil pekerjaan NA pada soal 3

Pada subjek dengan kemampuan matematika rendah, AR hanya mengalami keempat tahapan IDEAL. Pada tahap meingidentifikasi masalah soal ketiga, AR menuliskan apa yang diketahui dalam soal, yaitu $x+y+5=55$ dan $5 x=6 y$. Pada tahap mendefinisikan masalah, AR menuliskan apa yang ditanyakan yaitu umur ayah dan umur anaknya, selanjutnya pada tahap mengeksplorasi strategi yang mungkin, AR memikirkan rencana yang akan digunakan untuk memecahkan masalah tersebut. Pertama AR akan merubah ke dalam bentuk kalimat matematika terlebih dahulu, kemudian AR mengeliminasi persamaan tersebut, dan yang terakhir AR menggunakan metode substitusi. Berikut cuplikan wawancara yang menunjukkan hal tersebut.

\section{R304 : Diubah dulu soal ceritanya jadi kalimat matematika, terus di eliminasi sama substitusi buat cari umur ayah dan umur anaknya.}

Pada tahap melaksanakan rencana, AR melaksanakan rencana sesuai yang sudah dibuatnya pada tahap sebelumnya, seperti yang terlihat pada Gambar 13. Pada tahap yang terakhir yaitu tahap mengkaji kembali dan mengevaluasi pengaruh, AR tidak melakukan pengecekan kembali. Jawaban yang didapatkan AR belum benar, meskipun AR merasa yakin akan jawaban yang telah diperolehnya.

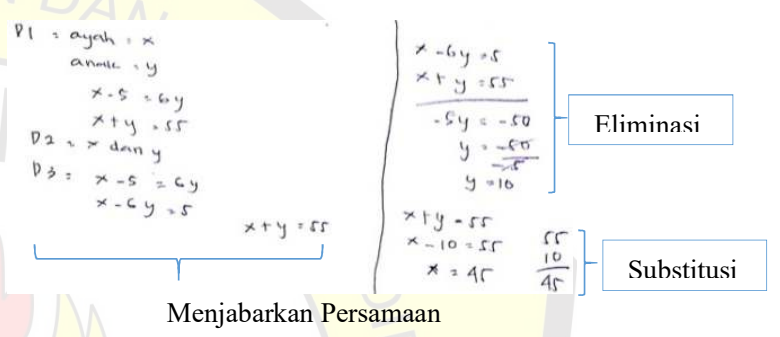

Gambar 13. Hasil pekerjaan NA pada soal 3

\section{Pembahasan}

Berdasarkan hasil tes dan paparan wawancara yang telah dibahas sebelumnya, tampak bahwa subjek dengan kemampuan matematika tinggi secara umum mampu memahami permasalahan yang diberikan, merumuskan masalah yang diberikan, mencari alternatif pemecahan masalah yang akan digunakan, dan melaksanakan pemecahan masalah secara bertahap, serta mengkaji kembali hasil yang diperoleh. Subjek dengan kemampuan matematika tinggi mampu melaksanakan kelima tahapan pemecahan masalah IDEAL. Namun demikian, pada soal ketiga yang berupa soal cerita, subjek belum mampu memahami dan merumuskan permasalahan yang diberikan. Hal tersebut bertentangan dengan hasil penelitian yang dilakukan oleh Agustina dkk (2014, hal. 20) 
yang menyatakan bahwa siswa yang memperoleh skor sempurna untuk merencanakan dan menyelesaikan masalah maka akan memperoleh skor sempurna untuk memahami masalah.

Subjek dengan kemampuan matematika sedang mampu memahami permasalahan secara umum, merumuskan masalah yang diberikan, mencari alternatif pemecahan masalah yang akan digunakan, dan melaksanakan pemecahan masalah secara bertahap, namun subjek belum mampu mengkaji kembali hasil yang diperolehnya. Selanjutnya pada subjek dengan kemampuan matematika rendah, subjek mengalami kebingungan dan kesulitan dalam melaksanakan rencana pemecahan masalahan dan mengkaji kembali hasil yang diperoleh. Hal tersebut dikarenakan subjek belum mampu dan ragu-ragu dalam mencari dan menyusun alternatif pemecahan masalah yang baik. Subjek hanya mampu memahami permasalahan secara umum, dan merumuskan masalah yang diberikan. Hal tersebut sesuai dengan penelitian yang dilakukan oleh Permata (2017, hal. 1) yang menyatakan bahwa siswa berkemampuan cukup/rendah kurang terampil dalam menemukan solusi.

Hasil penelitian juga menunjukkan bahwa ketiga subjek mengalami kesulitan dalam mengerjakan soal nomor tiga yaitu soal cerita. Hal tersebut diduga karena subjek belum mampu memahami permasalahan dengan baik, subjek juga salah dalam membuat model matematika, sehingga pada proses pengerjaan juga masih salah. Kurangnya latihan dalam mengerjakan soal cerita, juga karena tidak teliti dan tidak mengkaji ulang jawaban yang diperolehnya. Pernyataan tersebut selaras dengan penelitian yang dilakukan oleh Sulistyorini (2016, hal. 5) yang menyatakan bahwa kesulitan aspek memahami masalah yaitu siswa tidak biasa mengerjakan soal cerita dengan langkah pemecahan masalah, siswa salah dalam penulisan simbol, belum memahami konsep, dan siswa tidak dapat mengatur proses pengerjaan dengan baik; kesulitan aspek merencanakan yaitu siswa belum bisa membuat model matematika dan kemampuan siswa yang rendah dalam memahami masalah, dan kurangnya latihan soal; kesulitan aspek melaksanakan adalah kebiasaan siswa kurang teliti dalam perhitungan, langkah-langkah terlalu panjang, dan salah dalam membuat model matematika; kesulitan aspek melihat kembali adalah siswa tidak tahu cara melihat kembali yang benar, siswa tidak dapat mengatur waktu pengerjaan dengan baik, dan sikap malas siswa mengecek ulang jawaban.

\section{Simpulan dan Saran}

\section{Simpulan}

Berdasarkan analisis data dan pembahasan maka proses pemecahan masalah aljabar oleh siswa SMP berdasarkan tahap IDEAL dapat disimpulkan sebagai berikut.

1. Proses pemecahan masalah yang dialami oleh subjek dengan kemampuan matematika tinggi secara umum pada tahap mengidentifikasi masalah mampu memahami permasalahan yang diberikan, menganalisis permasalahan tersebut. Pada tahap mendefinisikan masalah, subjek mampu mencermati data yang sudah diketahui maupun yang belum diketahui, serta merumuskan masalah dalam soal, kemudian pada tahap mengeksplorasi strategi yang mungkin, subjek mampu mencari alternatif pemecahan masalah, dan memutuskan untuk memilih 
alternative untuk digunakan dalam pemecahan masalah. Pada tahap melaksanakan rencana, subjek mampu melaksanakan pemecahan masalah secara bertahap sesuai dengan rencana yang sudah dibuat pada tahap sebelumnya. Pada tahap yang terakhir yaitu tahap mengkaji kembali dan mengevaluasi pengaruh, subjek mampu mengkoreksi kembali cara-cara yang digunakan dalam pemecahan masalah, dan melihat pengaruh strategi yang digunakan dalam pemecahan masalah. Subjek dengan kemampuan matematika tinggi mampu melaksanakan kelima tahapan pemecahan masalah IDEAL.

2. Proses pemecahan masalah yang dialami oleh subjek dengan kemampuan matematika sedang secara umum pada tahap mengidentifikasi masalah mampu memahami permasalahan yang diberikan, menganalisis permasalahan tersebut. Pada tahap mendefinisikan masalah, subjek mampu mencermati data yang sudah diketahui maupun yang belum diketahui, serta merumuskan masalah dalam soal, kemudian pada tahap mengeksplorasi strategi yang mungkin, subjek mampu mencari alternatif pemecahan masalah, dan memutuskan untuk memilih alternative untuk digunakan dalam pemecahan masalah. Pada tahap melaksanakan rencana, subjek mampu melaksanakan pemecahan masalah secara bertahap sesuai dengan rencana yang sudah dibuat pada tahap sebelumnya. Pada tahap yang terakhir yaitu tahap mengkaji kembali dan mengevaluasi pengaruh, subjek belum mampu mengkaji kembali hasil yang diperolehnya. Subjek dengan kemampuan matematika sedang belum mampu melaksanakan kelima tahapan pemecahan masalah IDEAL. Subjek dengan kemampuan matematika sedang hanya melaksanakan keempat tahapan pemecahan masalah IDEAL.

Proses pemecahan masalah yang dialami oleh subjek dengan kemampuan matematika rendah secara umum pada tahap mengidentifikasi masalah mampu memahami permasalahan yang diberikan, menganalisis permasalahan tersebut. Pada tahap mendefinisikan masalah, subjek mampu mencermati data yang sudah diketahui maupun yang belum diketahui, serta merumuskan masalah dalam soal, kemudian pada tahap mengeksplorasi strategi yang mungkin, subjek mampu mencari alternatif pemecahan masalah, dan memutuskan untuk memilih alternative untuk digunakan dalam pemecahan masalah. Pada tahap melaksanakan rencana, subjek mengalami kebingungan dan kesulitan, hal tersebut dikarenakan subjek belum mampu dan ragu-ragu dalam mencari dan menyusun alternatif pemecahan masalah yang baik. Pada tahap yang terakhir yaitu tahap mengkaji kembali dan mengevaluasi pengaruh, subjek mampu mengkoreksi kembali cara-cara yang digunakan dalam pemecahan masalah, dan melihat pengaruh strategi yang digunakan dalam pemecahan masalah. Subjek hanya mampu memahami permasalahan secara umum, dan merumuskan masalah yang diberikan. Subjek dengan kemampuan matematika rendah belum mampu melaksanakan kelima tahapan pemecahan masalah IDEAL.

\section{Saran}

Penellitian tentang proses pemecahan masalah berdasarkan tahapan IDEAL dalam memecahkan masalah masih perlu untuk dikembangkan. Hasil penelitian yang 
menunjukkan bahwa siswa berkemampuan tinggi, sedang, maupun rendah belum mampu mengidentifikasikan masalah pada soal cerita menunjukkan masih perlunya dilakukan penelitian yang sejenis, untuk memperoleh hasil yang lebih valid. Temuan dalam penelitian ini juga belum ada tindak lanjutnya, sehingga disarankan untuk diadakan penelitian lain yang sejenis disertai dengan tindak lanjut dengan cara mengoptimalkan pengetahuan yang dimiliki siswa menggunakan tahapan pemecahan masalah IDEAL.

Untuk peneliti lain yang akan mengembangkan penelitian sejenis, alangkah baiknya jika mengembangkan penelitian dengan menggunakan jenjang yang berbeda. Hal ini bertujuan agar dapat mengetahui apakah hasil penelitian yang akan dilakukan tersebut apakah sama ataukah berbeda dengan hasil penelitian jenjangg SMP pada penelitian ini.

\section{Daftar Pustaka}

Djamarah, Saiful Bahri dan Zain, Aswan. 2002. Strategi Belajar Mengajar. Jakarta: Rineka Cipta.

Hammadah Iffih Awot S M, (2017). Profil Kemampuan Koneksi Matematika Dalam Memecahkan Soal Matematika Open-Ended Ditinjau Dari kemampuan Matematika. Jurnal Ilmiah Pendidikan Matematika, 2(6), 216-221.

J, B., \& Stein, B. 1993. The IDEAL Problem Solver: A Guide for Improving Thinking, Learning, and Creativity (2nd ed). New York: W.H. Freeman.

Munalikatasari, Dita Aprilia (2016). Representasi Siswa SMP Dalam Memecahkan Masalah Matematika Berdasarkan Kemampuan Matematika.
Jurnal Ilmiah Pendidikan Matematika, 3(5), 112-121.

Permata, LD. 2017. Kemampuan Pemecahan Masalah Matematika Pada Materi Faktorisasi Aljabar Berdasarkan Langkah Gagne Siswa Kelas VIII SMP Negeri 2 Gatak Tahun Ajaran 2016/2017. Diakses tanggal 12 Februari 2018 dari 